\title{
POTOCOLS OPTIMIZATION FOR IN VITRO PROPAGATION OF JATROPHA CURCAS
}

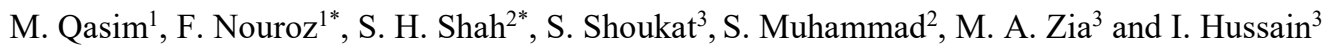 \\ ${ }^{1}$ Department of Botany, Hazara University, Mansehra, Pakistan; ${ }^{2}$ Department of Agricultural Sciences, Faculty of \\ Sciences, Allama Iqbal Open University, Islamabad, Pakistan \\ ${ }^{3}$ National Institute for Genomics and Advanced Biotechnology (NIGAB), National Agricultural Research Center \\ (NARC), Islamabad, Pakistan \\ *Corresponding author’s e-mail: faisalnouroz@gmail.com; sabir.hussain@aiou.edu.pk
}

\begin{abstract}
Jatropha curcas is a tremendous source of biodiesel with seeds containing 30-40\% oil contents. The plant also exhibits diverse medicinal values, but Jatropha production is negligible due to fluctuations in weather causing seed dormancy. The micropropagation of this economically important plant is the basic requirement of present era to cope its high demands for biodiesel production. Applications of various phytohormones significantly increase the micropropagation of Jatropha. The present study reveals that MS added with BAP $(1.0 \mathrm{mg} / \mathrm{l})$ media produced seeds germination and shoot induction in the shortest possible time $(10.18 \mathrm{~d})$ and $(10.60 \mathrm{~d})$, respectively., While MS media added with IBA (1.0 $\mathrm{mg} / \mathrm{l})$ presented less days to root initiation (10.64). The maximum germination percentage $(73.49 \%)$ was recorded on media containing BAP $(1.0 \mathrm{mg} / \mathrm{l})$, while less bacterial contamination $(1.61 \%)$ was recorded in MS plain media. MS media added with $\mathrm{GA}_{3}(1.0 \mathrm{mg} / \mathrm{l})$ exhibited the seeds germination in a very short time. The highest number of shoots (80) was found in MS supplemented with BAP $(1.0 \mathrm{mg} / \mathrm{l})$ in the seedlings. The MS media having 2, 4-D + BAP $(0.5$ $\mathrm{mg} / \mathrm{l})$ depicted maximum production of leaves-derived callus initiation $(100 \%)$. Then the plantlets were subjected to acclimatization and subsequently transferred to soil that reached to maturity and produced normal seeds. The optimized protocols for micropropagation would be beneficial for the mass production of economically important Jatropha plant.
\end{abstract}

Keywords: Biodiesel, In vitro, Jatropha curcas, Micropropagation, Plant tissue culture.

https://doi.org/10.36899/JAPS.2021.1.0207

Published online August 26, 2020

\section{INTRODUCTION}

Jatropha curcas L. locally named as "Jamalgota" belongs to family Euphorbiaceae. It is a perennial shrubby plant with seeds as a good source of biodiesel used in diesel engine. 30-40\% oil contents have been found in seeds (Kandpal and Madan, 1995). Oil contents of this plant are unsaturated fatty acids and nonedible. Seeds of this plant are exported to Marseille and Lisbon for oil extraction and saponification. The change in temperature and precipitation can stimulate seed dormancy in Jatropha. All components of Jatropha are poisonous in nature having toxic substances. In order to enhance the biodiesel production in Pakistan, Jatropha is being grown on a large scale. This plant contains high protein, carbohydrates and fiber contents i.e. 19\%, 17\% and $16 \%$, respectively in the pressed cake obtained from the seeds. Like chicken manure, the pressed cake is utilized as organic fertilizer (Makkar and Becker, 1997). Jatropha has toxic as well as medicinal values because all of its sections including seeds, leaves and bark decoction are used as drug and for veterinary purposes. Arthritis, jaundice, gout and contraceptives are found to be treated with these seeds. Antimicrobial activity and inhibition of watermelon mosaic virus have been observed by the use of latex. Also the enzymes isolated from latex have been found in healing wound (Thomas, 1989). This plant is of great medicinal importance because of having different compounds being used for tooth pain, inflammation and plant extract for allergies, wounds healing and burns. It is also used for smallpox, leucoderma and leprosy. Its branches are found to be used in the treatment of HIV and cancer (Sharma et al., 2012). Jatropha is considered as non-edible biofuel sources, while other plants such as sunflower, canola, mustard and rape seed are called $1^{\text {st }}$ generation biofuel sources. More attention is needed to grow Jatropha on a large scale production because Pakistan is deficient of biodiesel resources. The plant is difficult to cultivate due to long cultivation time and low yield. Therefore, it can be propagated via tissue culture techniques to reduce the problem of long-time cultivation and low yield (Thepsamran et al., 2006).

A large number of plants can be developed from small tissue of endangered species. The meristematic tip culture is preferred as this is considered as virus free region. Plant physiological condition induced the tissue culturing response in the plants. Better oil contents for biofuel production can be achieved via genetic transformation of $J$. curcas through transgenic techniques (Divakara et al., 2010). Jatropha seeds have poor seed viability, slow germination and delayed rooting. The seed 
production starts after 3-4 years and vegetative cuttings are seasonal and less tolerant to drought due to poor root system (Sujatha et al., 2005). Micro multiplication is the best approach to obtain large quantity of plants in the shortest period of time (Ahmad et al., 2012; Attaya et al., 2012; Uzma et al., 2012; Jan et al., 2015; Shah et al., 2015; Ali et al., 2017). Plant growth regulators are critical components of tissue culture media for plant growth and development (Shah et al., 2013; Shah et al., 2014 a-b; Shah et al., 2020). Keeping in view the economic importance of biofuels, the present study was designed to produce Jatropha saplings by tissue culture. The present research was a refinement in the previous research (Sujatha et al., 2005) work conducted on tissue culture of Jatropha, because more multiplication rate was recorded in the present study as compared to that of the previous research group. This study successfully established the culture initiation, micropropagation, callus induction and in vitro shoot regeneration in Jatropha curcas.

\section{MATERIALS AND METHODS}

The present study was accompanied in Plant Tissue Culture Laboratory, Plant Biotechnology Program, National Agricultural Research Center (NARC), Islamabad, Pakistan.

Sterilization of plant material: For the micropropagation, the seeds as explants were collected from fruits of Jatropha curcas. The fruits were soaked in detergents for 5-10 min and washed with distilled water for 5-6 times. The sliced fruits were used to collect seeds in a laminar flow hood observing all sterilized conditions to avoid contamination. The seeds were washed 3-4 times with sterilized water and then soaked in $20 \%$ Clorox for $20 \mathrm{~min}$ for sterilization. The seed coat was removed. The process of sterilization was performed using three different conc. of Clorox for twenty min and then seeds were soaked in sterilized water for the duration of $5 \mathrm{~min}$.

Media composition for culturing: After sterilization of seeds, they were dried out in the laminar flow hood and cultivated on culture medium (MS) having different conc. of hormones at $\mathrm{pH}$ 5.7-5.8. The fresh cultures were set aside in dark and after germination, they were put into light. The media used were MS plain media served as control along with MS media supplemented with four combinations of hormones i.e. BAP, NAA, IBA and $\mathrm{GA}_{3}$ at the concentration of $1.0 \mathrm{mg} / 1$.

Media composition for micro-propagation: The shoot tips from 3-week old seedlings were used as explants for micropropagation. MS plain media served as control, MS added with BAP $(0.5 \mathrm{mg} / \mathrm{l})+\mathrm{IAA}(0.5 \mathrm{mg} / \mathrm{l}), \mathrm{MS}$ added with BAP (1.0 mg/l) + IAA (0.5 mg/l), MS supplemented with BAP $(1.5 \mathrm{mg} / \mathrm{l})+$ IAA $(0.5 \mathrm{mg} / \mathrm{l})$ and $\mathrm{MS}$ supplemented with BAP $(0.5 \mathrm{mg} / \mathrm{l})+$ NAA $(1 \mathrm{mg} / \mathrm{l})$. Additional combinations of hormones tested for micropropagation were MS supplemented with BAP $(0.1$ $\mathrm{mg} / \mathrm{l})$, MS supplemented with BAP $(0.1 \mathrm{mg} / \mathrm{l})+\mathrm{IBA}(0.1$ $\mathrm{mg} / \mathrm{l})$, MS supplemented with Kinetin $(0.1 \mathrm{mg} / \mathrm{l})$, MS supplemented with Kin $(0.1 \mathrm{mg} / \mathrm{l})+\mathrm{IBA}(0.1 \mathrm{mg} / \mathrm{l}), \mathrm{MS}$ supplemented with Thidiazuron $(0.1 \mathrm{mg} / \mathrm{l})$ and $\mathrm{MS}$ supplemented with TDZ $(0.1 \mathrm{mg} / \mathrm{l})+$ IBA $(0.1 \mathrm{mg} / \mathrm{l})$.

Media composition for callus induction: Explants from various sources were transferred on medium and kept in photoperiod of $16 \mathrm{~h}$ at $25 \pm 2{ }^{\circ} \mathrm{C}$. Data were registered after two weeks of culturing. MS media was added with different combinations of hormones. MS plain media served as a control. MS supplemented with 2, 4-D (0.5 $\mathrm{mg} / \mathrm{l})+(0.5 \mathrm{mg} / \mathrm{l})$ and MS supplemented with $2,4-\mathrm{D}(0.5$ $\mathrm{mg} / \mathrm{l})+\mathrm{NAA}(0.5 \mathrm{mg} / \mathrm{l})$.

Media composition for in vitro rooting: From the bunch of multiple buds, the regenerated shoots were obtained and transferred on different rooting media as MS plain media (control having no hormone), MS + IBA (1.0 mg/l, $1.5 \mathrm{mg} / \mathrm{l}$ and $2.0 \mathrm{mg} / \mathrm{l}), \mathrm{MS}+\mathrm{NAA}(1.0 \mathrm{mg} / 1,1.5 \mathrm{mg} / \mathrm{l}$ and $2.0 \mathrm{mg} / \mathrm{l})$ and $\mathrm{MS}+\mathrm{GA}_{3}(1.0 \mathrm{mg} / 1,1.5 \mathrm{mg} / \mathrm{l}$ and 2.0 $\mathrm{mg} / \mathrm{l})$.

Statistical analysis: The data was statistically analyzed by using two way factorial design to study different factors i.e. culture initiation, seed germination, seedlings, and root formation, while CRD was used for micropropagation.

\section{RESULTS}

Seeds collection and sterilization: The fruits of Jatropha curcas were used as seed source for micropropagation. The seeds were removed from fruits with scalper and forceps in sterilized conditions in laminar flow hood, washed with distilled water (5-10 min) and sterilized with $20 \%$ Clorox for 20 min (Fig. 1a). The seed cover was removed from seeds for quick micropropagation, which were again rinsed with $0 \%$, $10 \%, 20 \%$, and $30 \%$ Clorox for $20 \mathrm{~min}$. The seeds were then soaked in sterilized water for $5 \mathrm{~min}$. The seeds fully sterilized were used for further micropropagation analysis.

Days to germination: Minimum germination days (10.18 days) were observed at BAP $(1.0 \mathrm{mg} / \mathrm{l})$ concentration in MS medium in Jatropha curcas, that have no significant difference with the other hormone concentrations i.e. NAA $(1.0 \mathrm{mg} / \mathrm{l})$, IBA $(1.0 \mathrm{mg} / \mathrm{l})$ and $\mathrm{GA}_{3}(1.0 \mathrm{mg} / \mathrm{l})$ showed days to germination of 10.83 , $10.968,11.38$, respectively, whereas, the MS plain media showed maximum days to germination (20.48) (Table 1).

Days of initiation of root formation: The factors under study like hormone combination, level of sterilization and 
their reciprocal action manifest highly significant results on days to profuse root production to sprouted seed. Minimum days (10.64) to root induction was observed at IBA $1.0 \mathrm{mg} / 1$ in seedling (Fig. 1b), while plain media showed maximum number of days (15.392) to root induction (Table 2). Similarly, variation was observed in seedlings of $J$. curcas at different sterilization levels, the highest number of days to root induction (15.153) were recorded on $30 \%$ sterilization level whereas minimum no. of days for root initiation (9.621) were recorded at $0 \%$ level of sterilization. Interaction assessment studies between growth media and sterilization process presented the least time duration to induce root formation (5.65) on BAP $(1.0 \mathrm{mg} / \mathrm{l})$ at $0 \%$ Clorox level, while supreme 23.22 root induction was observed on control at $20 \%$ Clorox level.

Days to shoot initiation: All the factors under study like hormone combination, level of sterilization and their influence showed highly significant impact on days to shoot initiation. Minimum days to shoot initiation (10.60) were observed at BAP $1.0 \mathrm{mg} / 1$ (Fig. 1c), while MS plain media showed maximum days to shoot induction (15.82) (Table 3). Likewise, least days to shoot induction (9.61) were observed on $0 \%$ Clorox and maximum 15.47 were recorded at 30\% Clorox concentration. Interaction effect of media and Clorox level showed that the lowest number of days to shoot induction (5.78) was observed at BAP $(1.0 \mathrm{mg} / \mathrm{l})$ and Clorox $(20 \%)$.

Sprouting percentage: Different media, Clorox level and their interaction presented the significant differences on the sprouting of seeds percentage. The highest sprouting percentage $(73.49 \%)$ was observed at BAP $(1.0$ $\mathrm{mg} / \mathrm{l})$ followed by $(73.36 \%)$ on MS plain media. The minimum germination percentage $(29.81 \%)$ was found on MS media supplemented with NAA (1.0 mg/l) (Table 4). Clorox levels showed significant difference on germination at $20 \%$ Clorox. The highest percentage of sprouting (63.77) was observed at $20 \%$ Clorox, while at $0 \%$ Clorox, the minimum percentage of sprouting was recorded. Media to Clorox concentration interaction presented the minimum sprouting percentage $(18.8 \%)$ at NAA $(1.0 \mathrm{mg} / \mathrm{l})$ and Clorox $(30 \%)$ The maximum sprouting percentage $(93.99 \%)$ was recorded at $\mathrm{GA}_{3}(1.0$ $\mathrm{mg} / \mathrm{l})$ with $10 \%$ Clorox level.

Bacterial contamination: MS plain media showed the least bacterial contamination i.e. $1.61 \%$, whereas, the maximum contamination was seen on NAA $(1.0 \mathrm{mg} / \mathrm{l})$ medium (Table 5). Highly significant differences were recorded on different Clorox levels in J. curcas seeds. The interaction studies of media and Clorox levels brought about low contamination on MS plain media at $0 \%, 20 \%$ and $30 \%$ Clorox levels. The highest bacterial contamination $(24.69 \%)$ was observed at MS media enriched with NAA $(1.0 \mathrm{mg} / \mathrm{l})$ and $30 \%$ Clorox level.
Fungal contamination: MS media having BAP (1.0 $\mathrm{mg} / \mathrm{l})$ produced high fungal contamination i.e. $7.76 \%$ (Table 6). Likewise, highly significant impact was recorded by different Clorox levels in J. curcas seeds. $0 \%$ fungal harm was observed at 20 and $30 \%$ Clorox levels. The reciprocal studies of media and Clorox levels brought about low fungal contamination on BAP (1.0 $\mathrm{mg} / \mathrm{l})$ and $\mathrm{GA}_{3}(1.0 \mathrm{mg} / \mathrm{l})$ at all sterilization levels. The highest contamination $(31.03 \%)$ of fungus was observed at MS plain along with $10 \%$ Clorox level.

Callogenesis: The seedlings of $J$. Curcus were selected for callus formation and transferred on MS media having different hormonal combinations. The highest callus induction percentage $(58 \%)$ was observed at $2,4-\mathrm{D}+$ BAP at $0.5 \mathrm{mg} / \mathrm{l}$, respectively, with whitish soft callus ( $\sim 39$ g) (Fig. 1d-e). $0 \%$ callus was observed at MS plain media (Table 8). The highest percentage of callus initiation $(100 \%)$ was recorded on MS plain media supplemented with 2, 4-D $(0.5 \mathrm{mg} / \mathrm{l})+$ BAP $(0.5 \mathrm{mg} / \mathrm{l})$ followed by MS plain media having 2, 4-D $(0.5 \mathrm{mg} / \mathrm{l})+$ NAA $(0.5 \mathrm{mg} / \mathrm{l})$. Texture, color and mass of the callus had variations. Good callus $1.47 \mathrm{~g}$ in weight with yellow color was recorded on MS media enriched with 2, 4-D $(0.5 \mathrm{mg} / \mathrm{l})+\mathrm{BAP}(0.5 \mathrm{mg} / \mathrm{l})$, minimum weighted $0.36 \mathrm{~g}$ green callus was recorded on control medium (Table 8). The maximum callus initiation $(100 \%)$ with yellow white color having soft texture of 1.16 gram was observed at MS media with 2, 4-D $(0.5 \mathrm{mg} / \mathrm{l})+\mathrm{BAP}(0.5 \mathrm{mg} / \mathrm{l})$, while $0 \%$ of callus induction was observed at MS plain media (Table 8).

Micropropagation: The maximum number of shoots (0.80) was recorded on MS media supplemented with BAP $(1.0 \mathrm{mg} / \mathrm{l})$ (Fig. 1f-h), while minimum number of shoots (0.32) was recorded on MS media enriched with NAA $(1.0 \mathrm{mg} / \mathrm{l})$. At $20 \%$ Clorox concentration, the no. of shoots was 0.66 , while less no. of shoots $(0.51)$ was noticed at 30\% Clorox (Table 7). The interaction effect of Clorox level with media demonstrated high number of shoots (1.16) on MS + BAP (1.0 mg/l) and 30\% sterilization level. After two weeks at $1.0 \mathrm{mg} / \mathrm{l}$ of BAP, 1.33 shoots were observed, while few shoots 0.83 were observed on $0.1 \mathrm{mg} / 1$ of TDZ and IBA in combination. BAP $(1.0 \mathrm{mg} / 1)$ showed 2.01 maximum number of shoots whereas the minimum number of shoots $(0.84)$ were observed at TDZ $(0.1 \mathrm{mg} / \mathrm{l})+\operatorname{IBA}(0.1 \mathrm{mg} / \mathrm{l})$.

In vitro rooting: The maximum number of roots (3.17) were observed on MS plain media that are statistically justified with the no. of roots 3.11 on MS media supplemented with $\mathrm{GA}_{3}(1.0 \mathrm{mg} / \mathrm{l})$, while minimum no. of roots (1.12) were recorded at MS media having NAA $(1.0 \mathrm{mg} / \mathrm{l})$ (Table 9). When the collective effect was observed for sterilization along with media, this showed that $1.0 \mathrm{mg} / \mathrm{l}$ of $\mathrm{GA}_{3}$ increased the number of roots $(4.21)$ on 10\% Clorox level (Table 9). MS media added with 
IBA showed good results i.e. 1.56 percent roots where $\mathrm{GA}_{3}$ showed no results. The combined effect of media and hormones resulted in the increased no. of roots 1.93 on IBA $2.0 \mathrm{~m} / \mathrm{l}$, while low to no roots were observed in case of $\mathrm{GA}_{3}$ at all hormonal concentrations. The overall effect of media with hormones after six weeks induced the highest number of roots that was 3.09 at $3.0 \mathrm{mg} / \mathrm{lBA}$ level, while low to no roots were observed in case of $\mathrm{GA}_{3}$ following 1.0 and $1.5 \mathrm{mg} / \mathrm{l}$ concentrations. After 8 weeks, high no. of root formation was observed. IBA concentrations along with MS media were found to be the best for root formation (3.34), while $\mathrm{GA}_{3}$ showed minimum root formation (0.003). After eight weeks, the interaction studies showed that IBA at $2.0 \mathrm{mg} / 1$ showed maximum no. of roots (4.09) (Fig. 1i-j), and minimum no. of roots in $1.0 \mathrm{mg} / \mathrm{l}$ and $1.5 \mathrm{mg} / \mathrm{G} \mathrm{GA}_{3}$. The rooted plants were shifted to greenhouse for acclimatization (Fig. 1k-1).

Table 1. Assessment of media and sterilization on days to seed germination in Jatropha curcas.

\begin{tabular}{llllll}
\hline Media & \multicolumn{5}{c}{ Sterilization } \\
\cline { 2 - 6 } & $\mathbf{0 \%}$ & $\mathbf{1 0 \%}$ & $\mathbf{2 0 \%}$ & $\mathbf{3 0 \%}$ & Mean \\
\hline MS plain & 7.73 & 28.09 & 23.43 & 22.67 & $20.48^{\mathrm{a}}$ \\
MS + BAP (1.0 mg/l) & 5.67 & 12.38 & 5.86 & 16.80 & $10.18^{\mathrm{b}}$ \\
MS + NAA (1.0 mg/l) & 10.39 & 11.08 & 11.59 & 10.25 & $10.83^{\mathrm{b}}$ \\
MS + IBA (1.0 mg/l) & 9.23 & 12.56 & 8.82 & 13.28 & $10.97^{\mathrm{b}}$ \\
MS + GA 3 (1.0 mg/l) & 12.33 & 10.61 & 10.63 & 11.94 & $11.38^{\mathrm{b}}$ \\
Mean & 9.07 & 14.95 & 12.07 & 14.99 & \\
\hline
\end{tabular}

Means followed by different letters were statistically different at 5\% level of probability. LSD value for media at 5\% of probability was 6.54 , while LSD value for sterilization at $5 \%$ of probability was 5.85 .

Table 2. Assessment of media and sterilization on days to root initiation in Jatropha curcas.

\begin{tabular}{llllll}
\hline Media & \multicolumn{5}{c}{ Sterilization } \\
\cline { 2 - 5 } & $\mathbf{0 \%}$ & $\mathbf{1 0 \%}$ & $\mathbf{2 0 \%}$ & $\mathbf{3 0 \%}$ & Mean \\
\hline MS plain & $8.01^{\mathrm{m}}$ & $7.84^{\mathrm{m}}$ & $23.22^{\mathrm{a}}$ & $22.52^{\mathrm{b}}$ & $15.40^{\mathrm{a}}$ \\
MS + BAP $(1.0 \mathrm{mg} / \mathrm{l})$ & $5.65^{\mathrm{o}}$ & $14.76^{\mathrm{d}}$ & $7.20^{\mathrm{n}}$ & $17.56^{\mathrm{c}}$ & $11.29^{\mathrm{d}}$ \\
MS + NAA $(1.0 \mathrm{mg} / \mathrm{l})$ & $12.98^{\mathrm{f}}$ & $13.49^{\mathrm{e}}$ & $11.40^{\mathrm{i}}$ & $10.37^{\mathrm{k}}$ & $12.06^{\mathrm{b}}$ \\
MS + IBA $(1.0 \mathrm{mg} / \mathrm{l})$ & $9.03^{1}$ & $11.33^{\mathrm{i}}$ & $8.85^{\mathrm{l}}$ & $13.39^{\mathrm{e}}$ & $10.65^{\mathrm{e}}$ \\
MS + GA $(1.0 \mathrm{mg} / \mathrm{l})$ & $12.46^{\mathrm{g}}$ & $10.63^{\mathrm{j}}$ & $10.72^{\mathrm{j}}$ & $11.95^{\mathrm{h}}$ & $11.44^{\mathrm{c}}$ \\
Mean & $9.63^{\mathrm{d}}$ & $11.61^{\mathrm{c}}$ & $12.28^{\mathrm{b}}$ & $15.16^{\mathrm{a}}$ \\
\hline Means followed by different letters were statistically different at 5\% level of probability. LSD value for media at $5 \%$ of probability \\
was 0.13, while LSD value for sterilization at 5\% of probability was 0.12. LSD for interaction of media and sterilization at 5\% of \\
probability was 0.26.
\end{tabular}

Table 3. Assessment of media and sterilization on days to shoot initiation in Jatropha curcas.

\begin{tabular}{llllll}
\hline Media & \multicolumn{5}{c}{ Sterilization } \\
\cline { 2 - 5 } & $\mathbf{0 \%}$ & $\mathbf{1 0 \%}$ & $\mathbf{2 0 \%}$ & $\mathbf{3 0 \%}$ & Mean \\
\hline MS plain & $8.30^{\mathrm{n}}$ & $8.02^{\mathrm{o}}$ & $23.80^{\mathrm{a}}$ & $23.15^{\mathrm{b}}$ & $15.82^{\mathrm{a}}$ \\
MS + BAP (1.0 mg/l) & $5.83^{\mathrm{p}}$ & $14.13^{\mathrm{d}}$ & $5.78^{\mathrm{p}}$ & $16.67^{\mathrm{c}}$ & $10.60^{\mathrm{e}}$ \\
MS + NAA (1.0 mg/l) & $12.02^{\mathrm{g}}$ & $14.29^{\mathrm{d}}$ & $11.22^{\mathrm{ij}}$ & $11.06^{\mathrm{k}}$ & $12.15^{\mathrm{b}}$ \\
MS + IBA (1.0 mg/l) & $9.50^{\mathrm{m}}$ & $11.63^{\mathrm{h}}$ & $9.73^{\mathrm{l}}$ & $14.25^{\mathrm{d}}$ & $11.28^{\mathrm{d}}$ \\
MS + GA $(1.0 \mathrm{mg} / \mathrm{l})$ & $12.4^{\mathrm{le}}$ & $11.25^{\mathrm{i}}$ & $11.08^{\mathrm{jk}}$ & $12.21^{\mathrm{f}}$ & $11.74^{\mathrm{c}}$ \\
Mean & $9.61^{\mathrm{d}}$ & $11.86^{\mathrm{c}}$ & $12.33^{\mathrm{b}}$ & $15.47^{\mathrm{a}}$ & \\
\hline
\end{tabular}

Means followed by different letters were statistically different at $5 \%$ level of probability. LSD value for media at $5 \%$ of probability was 0.09 , while LSD value for sterilization at $5 \%$ of probability was 0.08 . LSD for interaction of media and sterilization at $5 \%$ of probability was 0.17 . 
Table 4. Assessment of media and sterilization on seeds germination (\%) in Jatropha curcas.

\begin{tabular}{|c|c|c|c|c|c|}
\hline \multirow[t]{2}{*}{ Media } & \multicolumn{5}{|c|}{ Sterilization } \\
\hline & $0 \%$ & $10 \%$ & $20 \%$ & $30 \%$ & Mean \\
\hline MS plain & $83.12^{\mathrm{d}}$ & $68.61^{f}$ & $74.99^{\mathrm{e}}$ & $66.73^{g}$ & $73.36^{\mathrm{a}}$ \\
\hline $\mathrm{MS}+\mathrm{BAP}(1.0 \mathrm{mg} / \mathrm{l})$ & $56.34^{\mathrm{h}}$ & $56.42^{\mathrm{h}}$ & $93.55^{\mathrm{b}}$ & $87.64^{\mathrm{c}}$ & $73.49^{a}$ \\
\hline $\mathrm{MS}+\mathrm{NAA}(1.0 \mathrm{mg} / \mathrm{l})$ & $37.51^{\mathrm{j}}$ & $25.38^{\mathrm{k}}$ & $37.55^{\mathrm{j}}$ & $18.80^{1}$ & $29.81^{d}$ \\
\hline $\mathrm{MS}+\mathrm{IBA}(1.0 \mathrm{mg} / \mathrm{l})$ & $37.69^{\mathrm{j}}$ & $37.76^{\mathrm{j}}$ & $43.86^{\mathrm{i}}$ & $87.35^{\mathrm{c}}$ & $51.67^{\mathrm{c}}$ \\
\hline $\mathrm{MS}+\mathrm{GA}_{3}(1.0 \mathrm{mg} / \mathrm{l})$ & $56.21^{\mathrm{h}}$ & $93.99^{\mathrm{a}}$ & $68.89^{f}$ & $56.12^{\mathrm{h}}$ & $68.80^{\mathrm{b}}$ \\
\hline Mean & $54.18^{d}$ & $56.43^{c}$ & $63.77^{\mathrm{a}}$ & $63.33^{\mathrm{b}}$ & \\
\hline
\end{tabular}

Means followed by different letters were statistically different at 5\% level of probability. LSD value for media at 5\% of probability was 0.23 , while LSD value for sterilization at $5 \%$ of probability was 0.2 . LSD for interaction of media and sterilization at $5 \%$ of probability was 0.45 .

Table 5. Assessment of media and sterilization on bacterial contamination in Jatropha curcas.

\begin{tabular}{llllll}
\hline Media & \multicolumn{3}{c}{ Sterilization } \\
\cline { 2 - 6 } & $\mathbf{0 \%}$ & $\mathbf{1 0 \%}$ & $\mathbf{2 0 \%}$ & $\mathbf{3 0 \%}$ & Mean \\
\hline MS plain & $0.00^{\mathrm{e}}$ & $6.43^{\mathrm{d}}$ & $0.00^{\mathrm{e}}$ & $0.00^{\mathrm{e}}$ & $1.61^{\mathrm{e}}$ \\
MS + BAP (1.0 mg/l) & $12.67^{\mathrm{c}}$ & $18.68^{\mathrm{b}}$ & $6.13^{\mathrm{d}}$ & $6.17^{\mathrm{d}}$ & $10.91^{\mathrm{c}}$ \\
MS + NAA (1.0 mg/l) & $24.15^{\mathrm{a}}$ & $6.21^{\mathrm{d}}$ & $0.00^{\mathrm{e}}$ & $24.57^{\mathrm{a}}$ & $13.74^{\mathrm{b}}$ \\
MS + IBA (1.0 mg/l) & $24.26^{\mathrm{a}}$ & $24.45^{\mathrm{a}}$ & $24.69^{\mathrm{a}}$ & $0.00^{\mathrm{e}}$ & $18.35^{\mathrm{a}}$ \\
MS + GA 3 (1.0 mg/l) & $12.23^{\mathrm{c}}$ & $0.00^{\mathrm{e}}$ & $0.00^{\mathrm{e}}$ & $24.34^{\mathrm{a}}$ & $9.15^{\mathrm{d}}$ \\
Mean & $14.67^{\mathrm{a}}$ & $11.15^{\mathrm{b}}$ & $6.17^{\mathrm{c}}$ & $11.02^{\mathrm{b}}$ & \\
\hline
\end{tabular}

Means followed by different letters were statistically different at $5 \%$ level of probability. LSD value for media at $5 \%$ of probability was 0.39 , while LSD value for sterilization at $5 \%$ of probability was 0.35 . LSD for interaction of media and sterilization at $5 \%$ of probability was 0.77 .

Table 6. Assessment of media and sterilization on fungal contamination in Jatropha curcas.

\begin{tabular}{|c|c|c|c|c|c|}
\hline \multirow[t]{2}{*}{ Media } & \multicolumn{5}{|c|}{ Sterilization } \\
\hline & $0 \%$ & $10 \%$ & $20 \%$ & $30 \%$ & Mean \\
\hline MS plain & $8.35^{\mathrm{d}}$ & $31.03^{\mathrm{a}}$ & $0.00^{\mathrm{e}}$ & $0.00^{\mathrm{e}}$ & $2.08^{d}$ \\
\hline $\mathrm{MS}+\mathrm{BAP}(1.0 \mathrm{mg} / \mathrm{l})$ & $0.00^{\mathrm{e}}$ & $0.00^{\mathrm{e}}$ & $0.00^{\mathrm{e}}$ & $0.00^{\mathrm{e}}$ & $7.76^{\mathrm{a}}$ \\
\hline $\mathrm{MS}+\mathrm{NAA}(1.0 \mathrm{mg} / \mathrm{l})$ & $0.00^{\mathrm{e}}$ & $24.78^{\mathrm{b}}$ & $0.00^{\mathrm{e}}$ & $0.00^{\mathrm{e}}$ & $6.20^{\mathrm{b}}$ \\
\hline $\mathrm{MS}+\mathrm{IBA}(1.0 \mathrm{mg} / \mathrm{l})$ & $18.69^{c}$ & $0.00^{\mathrm{e}}$ & $0.00^{\mathrm{e}}$ & $0.00^{\mathrm{e}}$ & $4.68^{c}$ \\
\hline $\mathrm{MS}+\mathrm{GA}_{3}(1.0 \mathrm{mg} / \mathrm{l})$ & $0.00^{\mathrm{e}}$ & $0.00^{\mathrm{e}}$ & $0.00^{\mathrm{e}}$ & $0.00^{\mathrm{e}}$ & $0.00^{\mathrm{e}}$ \\
\hline Mean & $11.62^{\mathrm{a}}$ & $4.96 \mathrm{~b}$ & $0.00^{\mathrm{e}}$ & $0.00^{\mathrm{e}}$ & \\
\hline
\end{tabular}

Means followed by different letters were statistically different at 5\% level of probability. LSD value for media at 5\% of probability was 0.17 , while LSD value for sterilization at $5 \%$ of probability was 0.15 . LSD for interaction of media and sterilization at $5 \%$ of probability was 0.33 .

Table 7. Assessment of media and sterilization on number of seedlings shoots in Jatropha curcas.

\begin{tabular}{|c|c|c|c|c|c|}
\hline \multirow[t]{2}{*}{ Media } & \multicolumn{5}{|c|}{ Sterilization } \\
\hline & $\mathbf{0 \%}$ & $10 \%$ & $20 \%$ & $30 \%$ & Mean \\
\hline MS plain & $0.84^{\mathrm{d}}$ & $0.69^{\mathrm{e}}$ & $0.65^{f}$ & $0.52^{\mathrm{h}}$ & $0.68^{\mathrm{b}}$ \\
\hline $\mathrm{MS}+\mathrm{BAP}(1.0 \mathrm{mg} / \mathrm{l})$ & $0.63^{\mathrm{f}}$ & $0.45^{\mathrm{i}}$ & $1.16^{\mathrm{a}}$ & $0.96^{\mathrm{b}}$ & $0.80^{\mathrm{a}}$ \\
\hline $\mathrm{MS}+\mathrm{NAA}(1.0 \mathrm{mg} / \mathrm{l})$ & $0.44^{\mathrm{i}}$ & $0.25^{\mathrm{k}}$ & $0.34^{\mathrm{j}}$ & $0.24^{\mathrm{k}}$ & $0.32^{\mathrm{d}}$ \\
\hline $\mathrm{MS}+\mathrm{IBA}(1.0 \mathrm{mg} / \mathrm{l})$ & $0.33^{\mathrm{j}}$ & $0.26^{\mathrm{k}}$ & $0.42^{\mathrm{i}}$ & $0.71^{\mathrm{e}}$ & $0.43^{\mathrm{c}}$ \\
\hline $\mathrm{MS}+\mathrm{GA}_{3}(1.0 \mathrm{mg} / \mathrm{l})$ & $0.57^{\mathrm{g}}$ & $0.89^{c}$ & $0.71^{\mathrm{e}}$ & $0.58^{\mathrm{g}}$ & $0.69^{b}$ \\
\hline Mean & $0.56^{\mathrm{c}}$ & $0.51^{\mathrm{d}}$ & $0.66^{\mathrm{a}}$ & $0.60^{\mathrm{b}}$ & \\
\hline
\end{tabular}

Means followed by different letters were statistically different at $5 \%$ level of probability. LSD value for media at $5 \%$ of probability was 0.02 , while LSD value for sterilization at $5 \%$ of probability was 0.02 . LSD for interaction of media and sterilization at $5 \%$ of probability was 0.04 . 
Table 8. Assessment of media and sterilization on calli induction from different explant sources in Jatropha curcas.

\begin{tabular}{|c|c|c|c|c|c|c|c|c|c|c|c|c|}
\hline \multirow[t]{2}{*}{ Media } & \multicolumn{4}{|c|}{ Roots-derived calli induction } & \multicolumn{4}{|c|}{ Stems-derived calli induction } & \multicolumn{4}{|c|}{ Leaves-derived calli induction } \\
\hline & $\begin{array}{l}\text { C.I. } \\
(\%) \\
\end{array}$ & $\begin{array}{l}\text { Callus } \\
\text { Color } \\
\end{array}$ & $\begin{array}{l}\text { Callus } \\
\text { Texture }\end{array}$ & $\begin{array}{l}\text { Callus } \\
\text { Mass } \\
\end{array}$ & $\begin{array}{l}\text { C.I. } \\
(\%) \\
\end{array}$ & $\begin{array}{l}\text { Callus } \\
\text { Color } \\
\end{array}$ & $\begin{array}{l}\text { Callus } \\
\text { Texture }\end{array}$ & $\begin{array}{l}\text { Callus } \\
\text { Mass } \\
\end{array}$ & $\begin{array}{l}\text { C.I. } \\
(\%) \\
\end{array}$ & $\begin{array}{l}\text { Callus } \\
\text { Color }\end{array}$ & $\begin{array}{l}\text { Callus } \\
\text { Texture }\end{array}$ & $\begin{array}{l}\text { Callus } \\
\text { Mass }\end{array}$ \\
\hline MS plain media & $0.00 \%$ & - & - & - & $100 \%$ & $\begin{array}{l}\text { White } \\
\text { Green }\end{array}$ & Soft & $0.36 \mathrm{~g}$ & $0.00 \%$ & - & - & - \\
\hline $\begin{array}{l}\mathrm{MS}+2,4-\mathrm{D}(0.5 \\
\mathrm{mg} / \mathrm{l})\end{array}$ & $37.5 \%$ & White & Soft & $0.38 \mathrm{~g}$ & $100 \%$ & $\begin{array}{l}\text { Green } \\
\text { Brown }\end{array}$ & $\begin{array}{l}\text { Soft to } \\
\text { Hard }\end{array}$ & $0.96 \mathrm{~g}$ & $38 \%$ & $\begin{array}{l}\text { Yellow } \\
\text { Green }\end{array}$ & $\begin{array}{l}\text { Hard to } \\
\text { Soft }\end{array}$ & $0.6 \mathrm{~g}$ \\
\hline $\begin{array}{l}\mathrm{MS}+2,4-\mathrm{D}(0.5 \\
\mathrm{mg} / \mathrm{l})+\mathrm{BAP}(0.5 \\
\mathrm{mg} / \mathrm{l})\end{array}$ & $58 \%$ & White & Soft & $0.39 \mathrm{~g}$ & $100 \%$ & $\begin{array}{l}\text { Yellow } \\
\text { White }\end{array}$ & Soft & $1.47 \mathrm{~g}$ & $100 \%$ & $\begin{array}{l}\text { Yellow } \\
\text { White }\end{array}$ & Soft & $1.16 \mathrm{~g}$ \\
\hline $\begin{array}{l}\mathrm{MS}+2,4-\mathrm{D}(0.5 \\
\mathrm{mg} / \mathrm{l})+\mathrm{NAA}(0.5 \\
\mathrm{mg} / \mathrm{l})\end{array}$ & $50 \%$ & $\begin{array}{l}\text { White } \\
\text { Brown }\end{array}$ & Soft & $0.33 \mathrm{~g}$ & $100 \%$ & $\begin{array}{l}\text { Green } \\
\text { Brown }\end{array}$ & $\begin{array}{l}\text { Hard to } \\
\text { Soft }\end{array}$ & $1.36 \mathrm{~g}$ & $37.5 \%$ & $\begin{array}{l}\text { White } \\
\text { Green }\end{array}$ & Soft & $0.8 \mathrm{~g}$ \\
\hline
\end{tabular}

C.I. indicates Calli induction

Table 9. Assessment of media and sterilization on number of seedlings roots in Jatropha curcas.

\begin{tabular}{|c|c|c|c|c|c|}
\hline \multirow[t]{2}{*}{ Media } & \multicolumn{5}{|c|}{ Sterilization } \\
\hline & $0 \%$ & $10 \%$ & $20 \%$ & $30 \%$ & Mean \\
\hline MS plain & $3.84^{\mathrm{b}}$ & $2.84^{\mathrm{f}}$ & $3.19^{\mathrm{e}}$ & $2.82^{\mathrm{f}}$ & $3.17^{\mathrm{a}}$ \\
\hline $\mathrm{MS}+\mathrm{BAP}(1.0 \mathrm{mg} / \mathrm{l})$ & $2.40^{\mathrm{hi}}$ & $1.39^{\mathrm{jk}}$ & $3.58^{\mathrm{cd}}$ & $2.64^{\mathrm{fg}}$ & $2.50^{\mathrm{b}}$ \\
\hline $\mathrm{MS}+\mathrm{NAA}(1.0 \mathrm{mg} / \mathrm{l})$ & $1.53^{\mathrm{j}}$ & $0.89^{\mathrm{m}}$ & $1.24^{\mathrm{kl}}$ & $0.84^{\mathrm{m}}$ & $1.12^{\mathrm{d}}$ \\
\hline $\mathrm{MS}+\mathrm{IBA}(1.0 \mathrm{mg} / \mathrm{l})$ & $1.39^{\mathrm{jk}}$ & $1.15^{1}$ & $2.40^{\mathrm{hi}}$ & $3.64^{\mathrm{bc}}$ & $2.14^{\mathrm{c}}$ \\
\hline $\mathrm{MS}+\mathrm{GA}_{3}(1.0 \mathrm{mg} / \mathrm{l})$ & $2.25^{\mathrm{i}}$ & $4.21^{\mathrm{a}}$ & $3.40^{\mathrm{de}}$ & $2.58^{\mathrm{gh}}$ & $3.11^{\mathrm{a}}$ \\
\hline Mean & $2.28^{\mathrm{c}}$ & $2.10^{\mathrm{d}}$ & $2.76^{\mathrm{a}}$ & $2.50^{\mathrm{b}}$ & \\
\hline
\end{tabular}

Means followed by different letters were statistically different at $5 \%$ level of probability. LSD value for media at $5 \%$ of probability was 0.106 , while LSD value for sterilization at

$5 \%$ of probability was 0.1 . LSD for interaction of media and sterilization at $5 \%$ of probability was 0.22 . 

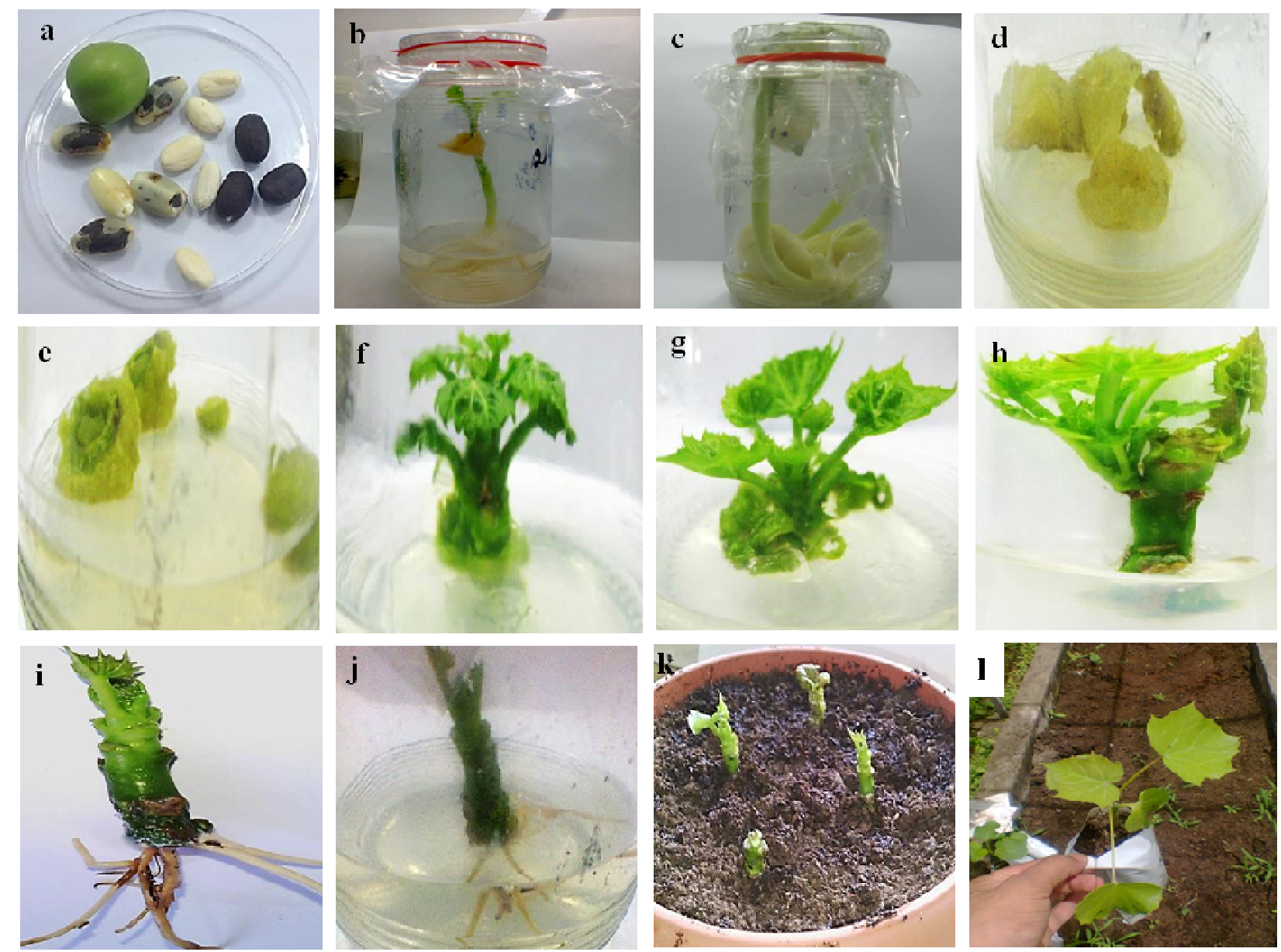

Fig. 1. In vitro propagation of Jatropha curcas. a. Fruit and seeds. b. Root initiation on MS + IBA (1.0 mg/l). c. Shoot initiation on MS + BAP (1.0 mg/l). d-e. Callus on MS + 2, 4-D (0.5 mg/l) + BAP (0.5 mg/l). f-h. Micropropagated shoots on MS + BAP (1mg/l). i-j In vitro rooting on MS + IBA (2mg/l). k-l. Acclimatization of $J$. curcas in peat moss.

\section{DISCUSSION}

Jatropha curcas is rarely cultivated via seeds due to low seed viability, seed dormancy, special environmental conditions and time to germination. In vitro propagation is the best solution to germinate it on suitable media. Results of this study showed that MS media added with plant hormones initiated the seed germination effectively. All the hormones presented the different response of micro propagation. Studies in Sinapis alba revealed that plant hormones specially BAP played a major role in its regeneration (Abbasi et al., 2011). Our studies are in line with Nunes et al. (2008) for sustainable, quick and continuous growth of Jatropha curcas. Kumari et al. (2010) stated that the seeds of $J$. curcas have limited viability. Sprouting of seeds is a chief character for any crop plant because optimum seed sprouting of crop can be used to optimize yield and quality of crops. In labs, sprouting is considerably enhanced by MS media added with different hormones, sterilization solution and interaction studies of media with sterilization levels. Among all tested treatments, the maximum seed sprouting percentage was observed on BAP at $20 \%$ Clorox level. In contrast, improved propagation percentage of Jatropha seeds by the application of gibberellins has been reported by Xun et al. (2012). Our findings showed the minimum days to initiate the shoot on BAP $(1.0 \mathrm{mg} / \mathrm{l})$.

In the present study, minimum root induction was observed on MS media supplemented with IBA (1.0 $\mathrm{mg} / \mathrm{l})$. These outcomes are clear reflection of Deore and Johnson (2008) research where the MS media containing $1.0 \mathrm{mg} / \mathrm{l} \mathrm{IBA}$ produced the well formulated roots within one month. Likewise, maximum root induction $(85.71 \%)$ has already been reported by Thepsamran et al. (2008) at $1.0 \mathrm{mg} / \mathrm{l} \mathrm{IBA.} 60 \%$ of the root formation has been reported by Kaewpoo and Techato (2009) at $0.5 \mathrm{mg} / \mathrm{l}$ IBA. Plant growth regulators affect the height of shoots, which in response increases the yield of a plant. The highest shoot length was observed on MS medium with 
$\mathrm{GA}_{3}$ for $J$. curcas as different plants hormone have different effect on plant growth. Shrivastava and Banjerjee (2008) recorded the maximum length of shoot at BAP and IBA $(3+1) \mathrm{mg} / \mathrm{l}$ concentration added in MS medium. The earlier results showed that the addition of $\mathrm{GA}_{3}$ and BAP can significantly result in shoot elongation (Jeevan et al., 2013). Maximum shoot size already has been reported by Shrivastava and Banjerjee (2008) who reported that half strength MS media along with IBA (3.0 $\mathrm{mg} / \mathrm{l}$ ) yielded the maximum shoot size. Mve et al. (2013) reported maximum root size on $2.46 \mu \mathrm{M}$ IBA along with $2 \%$ sucrose.

Seeds should be sterilized with proper chemicals in order to achieve surface sterilization via mercuric chloride or Clorox (bleach) in particular concentrations. In our findings, $20 \%$ Clorox level was used to control maximum contamination. $30 \%$ Clorox resulted in minimum contamination but the germination was too low. Our findings were in line with the results of Alla et al. (2013) who used 20\% Clorox for sterilization purpose. Callus is used for transformation purpose. The parameter to check the good callus must be soft, whitish or yellowish having maximum mass. This study showed the best type of callus in different explants i.e. root, stem and leaf on MS media having concentration 2, 4-D and BAP $(0.5 \mathrm{mg} / \mathrm{l})$ in combinations. The present findings are supported by Maharana et al. (2012); Rampadarath et al. (2014) who achieved the significant callus initiation with combination of 2, 4-D and BAP.

In micropropagation, no. of shoots formed is very important for the increasing the no. of plants. Cytokinin has been observed as the best shoot initiation agent in Jatropha curcas. Among different combinations of hormones, BAP $(0.1 \mathrm{mg} / \mathrm{l})$ yielded the maximum number of shoots. Several previous studies confirmed that BAP showed maximum shoot induction and shoot numbers. In Ziziphora tenuior (antimicrobial plant), the maximum shoot number (5.12) was observed on BAP @ $2.0 \mathrm{mg} / 1$ revealing the enhancing effect of BAP on shoot number (Dakah et al., 2014). Similarly, the highest rate of shoot regeneration $(85 \%)$ and shoot number/explants (5.6) in Dracaena sanderiana were achieved on medium + BAP@ $7.84 \mu \mathrm{M}$ (Aslam et al., 2013). Jeevan et al. (2013) investigated and reported the highest shoot frequency from Jatropha plant on MS medium containing BAP and IBA $(0.5 \mathrm{mg} / \mathrm{l})$ and $(0.1 \mathrm{mg} / \mathrm{l})$, respectively. Likewise Shukla et al. (2013) reported the initiation of buds from Jatropha curcas explants in which the highest number of buds was observed on BAP and IBA at $27.0 \mu \mathrm{M}$ and $3.0 \mu \mathrm{M}$, respectively.

In contrast, the shoot formation was observed in MS supplemented with Kin and TDZ by Kaewpoo and Te-chato (2010). Before shifting the laboratory propagated plants to outdoor setting, it is obligatory for plants to develop roots. In in vitro conditions, the rooting medium is added with root inducing hormones so that a plant can initiate roots. The media containing various concentrations of phytohormones especially auxins have been found to be excellent for root formation (Gunes, 2000). Our results indicate the elevated no. of roots on IBA $2.0 \mathrm{mg} / \mathrm{l}$ concentration which are confirmed by previous studies of Datta et al. (2007); Mve et al. (2013) who observed $19.43 \%$ of root formation in Jatropha.

Conclusion: The present study was an improvement in already established protocols and formulations of new protocols for explants sterilization, callogenesis, organogenesis and acclimatization of Jatropha curcas. The study confirmed that various hormonal combinations and concentrations showed significant results in micropropagation of Jatropha curcas, which can be utilized for the mass propagation of this highly economical plant. Sterilization of explants is important to avoid contaminations in micropropagation and present results confirmed that high percentages (20-30\%) of Clorox yielded the best microbial control.

Acknowledgements: The authors are grateful to Plant Tissue Culture Laboratory, National Institute for Genomics and Advanced Biotechnology (NIGAB), NARC, Islamabad, Pakistan for providing the opportunity to conduct this research work.

\section{REFERENCES}

Abassi, B. H., A. Rashid, M. A. Khan, M. Ali, Z.K. Shinwari, N. Ahmad, and T. Mahmood. (2013). In vitro plant regeneration in Sinapis alba and evaluation of radical scavenging activity. Pakistan J. Bot. 43(SI): 21-27.

Ahmad, M. Z., I. Hussain, S. Roomi, M. A. Zia, M. S. Zaman, Z. Abbas, and S. H. Shah (2012). In vitro response of cytokinin and auxin to multiple shoot regeneration in Solanum tuberosum L. American-Eurasian J. Agric. \& Environ. Sci. 12(11): 1522-1526.

Ali, S., S. Khan, S. H. Shah, A. Iqbal, M. A. Zia, and G. M. Ali (2017). Development of efficient regeneration and genetic transformation systems in local cultivars of chickpea (Cicer arietinum L.). J. Anim. Plant Sci. 27(6): 2025-2034.

Alla, A., N. Ragab, E. Mohamed, E. Miniawy, S. Deen, and T. Hussein. (2013). In vitro studies on cassava plant micropropagation of cassava (Manihot esculenta Crantz). J. Appl. Sci. Res. 9: 811-820.

Aslam, J., A. Mujib, and M. P. Sharma. (2013). In vitro micropropagation of Dracaena sanderiana Sander ex Mast: An important indoor ornamental plant. Saudi J. Biol. Sci. 20(1): 6368. 
Attaya, A. S., D. Geelen, and A. E. F. H. Belal. (2012). Progress in Jatropha curcas Tissue Culture. Am-Eurasian J. Sustain. Agric. 6: 6-13.

Dakah, A., S. Zaid, M. Suleiman, S. Abbas, and M. Wink. (2014). In vitro propagation of the medicinal plant Ziziphora tenuior $\mathrm{L}$. and evaluation of its antioxidant activity. Saudi J. Biol. Sci. 21(4): 317-321.

Datta, M. M., P. Mukherjee, B. Ghosh, and T. B. Jha. (2007). In vitro clonal propagation of biodiesel plant (Jatropha curcas L.). Curr. Sci. 93: 14381442.

Deore, A. C., and T. S. Johnson. (2008). High-frequency plant regeneration from leaf-disc cultures of $J$. curcas L.: an important biodiesel plant. Plant Biotech. Rep. 2: 7-11.

Divakara, B. N., H. D. Upadhyaya, S. P. Wani, and C. L. Gowda. (2010). Biology and genetic improvement of Jatropha curcas L.: A review. Appl. Ener. 87: 732-742.

Gunes, T. (2000). Peroxidase and IAA oxidase activities during rooting of poplar species. Turk. J. Bot. 24: 97-101.

Jan, S. A., S. H. Shah, S. Ali, and G. M. Ali (2015). The effect of plant growth regulators on the callus induction and somatic embryogenesis of hybrid tomato. Pakistan J. Bot. 47(5): 1671-1677.

Jeevan, P., A. Edith Rena, S. S. Subramanian, and R. Nelson. (2013). In vitro culture of Jatropha curcas L. - An important medicinal plant. $J$. Microbiol. Biotechnol. Res. 3: 44-48.

Kaewpoo, M., and S. Te-chato. (2010). Study on ploidy level of micropropagated Jatropha curcas L. via flow cytometry. J. Agric. Technol. 6: 391-400.

Kaewpoo, M., and S. Te-chato. (2009). Influence of explants types and plant growth regulators on multiple shoot formation from Jatropha curcas. Sci. Asia. 35: 353-357.

Makkar, H. P. S., and K. Becker. (1997). Jatropha curcas toxicity: identification of toxic principle (s). Pages 554-558 In: T Garland and AC Barr, editors. Toxic plants and other natural toxicants),. CAB International, New York, NY USA.

Kandpal, J. B., and M. Madan. (1995). Jatropha curcas-a renewable source of energy for meeting future energy needs. Renew Energ. 6: 159-160.

Kumari. M., V. Y. Patade, M. Arif, and Z. Ahmed. (2010). Effect of IBA on seed germination, sprouting and rooting in cuttings for mass propagation of Jatropha Curcus. Res. J. Agric. Biol. Sci. 6: 691-696.

Maharana, S. B., V. Mahato, M. Behera, R. R. Mishra, and J. Panigrahi. (2012). In vitro regeneration from node and leaf explants of Jatropha curcas and evaluation of genetic fidelity through RAPD markers. Indian J. Biotechnol. 11: 280-287.

Mve, S. D. M., G. Mergeai, P. Druart, J. P .Baudoin, and A. Toussaint. (2013). In vitro micropropagation of Jatropha curcas L. from bud aggregates. J. Technol. Innov. Renew. Energy, 2: 145-154.

Nunes, C. F., M. Pasqual, D. N. Santos, T. N. Custódio, and A. G. Araújo. (2008). Diferentes suplementos no cultivo in vitro de embriões de pinhão-manso. Pesq. Agropec. Bras. 43: 9-14.

Rampadarath, S., D. Puchooa, and M. R. Sanmukhiya. (2014). Optimized in vitro plant regeneration of the biodiesel plant Jatropha curcas L.: the effects of using seeds at different stages of maturity as starting materials. Int. J. Plant Biol. 5: 5448.

Shah, S. H., S. Ali, and G. M. Ali (2013). A novel approach for rapid in vitro morphogenesis in tomato (Solanum lycopersicum Mill.) with the application of cobalt chloride. Eur. Acad. Res. 1(9): 2702-2721.

Shah, S. H., S. Ali, S. A. Jan, and G. M. Ali (2014a). Assessment of carbon sources on in vitro shoot regeneration in tomato. Pakistan J. Agr. Sci. 51(1): 197-207.

Shah, S. H., S. Ali, S. A. Jan, J. U. Din, and G. M. Ali (2014b). Assessment of silver nitrate on callus induction and in vitro shoot regeneration in tomato (Solanum lycopersicum Mill.). Pakistan J. Bot. 46(6): 2163-2172.

Shah, S. H., S. Ali, S. A. Jan, J. U. Din, and G. M. Ali (2015). Callus induction, in vitro shoot regeneration and hairy root formation by the assessment of various plant growth regulators in tomato (Solanum lycopersicum Mill.). J. Anim. Plant Sci. 25(2): 528-538.

Shah, S. H., N. Khan, S. Q. Memon, M. Latif, M. A. Zia, A. Muhammad, K. Nasir and Zafarullah. (2020). Effects of auxins and cytokinins on in vitro multiplication of banana (Musa spp.) variety 'W-11' in Pakistan. J. Anim. Plant Sci. 30(1): 98-106.

Sharma. S., H. K. Dhamija, and B. Parashar. (2012). A review article on Jatropha curcus. Asian J. Res. Pharm. Sci. 2: 107-111.

Shrivastava, S., and M. Banjerjee. (2008). In vitro clonal propagation of physic nut (Jatropha curcas) influence of additives. Int. J. Integr. Biol. 3(1): 73-79.

Shukla, P., V. Makwana, D. Bhatt, and P. Robin. (2013). Efficient method for direct and indirect organogenesis in biofuel crop Jatropha curcas. Int. J. Pharm. Bio. Sci. 4: 673-682.

Sujatha, M., H. P. S. Makkar, and K. Becker. (2005). Shoot bud proliferation from axillary nodes and 
leaf sections of non-toxic J. curcas L. Plant Grow. Reg. 47: 83-90.

Thepsamran, N., C. Thepsithar, and A. Thongpukdee. (2008). In vitro induction of shoots and roots from J. curcas L. explants. J. Hort. Sci. Biotech. 83: 106-112.

Thepsamran, N., C. Thepsithar, and A. Thongpukdee. (2006). In vitro shoot induction of physic nut $(J$. curcas L.) Nakhon Pathom: Department of Biology, Faculty of Science, Silpakorn University, Thailand.

Thomas, O. O. (1989). Re-examination of the antimicrobial activities of Xylopia aethiopica,
Carica papaya, Ocimum gratissimum and Jatropha curcas. Fitoterapia. 60: 147-155.

Uzma, M. R. Khan, A. Muhammad, I. Hussain, S. H. Shah, T. Kumar, S. Inam, M. Zubair, H. U. Rehman, A. Sher, N. Rehman, S. Ahmed, and G. M. Ali (2012). Rapid in vitro multiplication of sugarcane elite genotypes and detection of sugarcane mosaic virus through two steps RTPCR. Int. J. Agric. Biol. 14(6): 870-878.

Xun, D., L. Z. Guang, and G. Ming. (2012). Effect of gibberellin, calcium, and betaine on seed germination and resistance of Jatropha curcas L. seedlings to low temperature and drought stress. Plant Sci. J. 30: 204-212. 